\title{
Enantiodivergent Synthesis of Halofuginone by Candida antarctica Lipase B (CAL-B)-Catalyzed Kinetic Resolution in Cyclopentyl Methyl Ether (CPME)
}

\author{
Elisa De Marchia (D) \\ Davide Arnodo ${ }^{b}$ (iD) \\ Elia Maffeisc (iD \\ Dina Scarpi ${ }^{a}$ \\ Cristina Prandib \\ Ernesto G. Occhiato*a (iD) \\ a Dipartimento di Chimica 'Ugo Schiff', Università degli Studi di Firenze, \\ Via della Lastruccia 13, 50019 Sesto Fiorentino (FI), Italy \\ ernesto.occhiato@unifi.it \\ b Dipartimento di Chimica, Università degli Studi di Torino, Via Pietro \\ Giuria 7, 10125 Torino, Italy \\ ' Huvepharma Italia, Via Lepetit 142, 12075 Garessio (CN), Italy
}

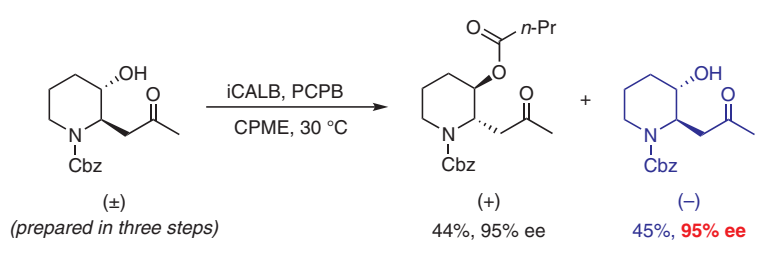

$\stackrel{\text { three steps }}{\longrightarrow}$

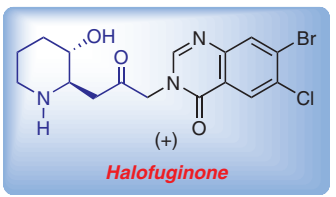

Received: 04.05.2021

Accepted after revision: 14.05 .2021

Published online: 07.06.2021

DOI: 10.1055/a-1523-6428; Art ID: so-2021-d0024-op

License terms: $c(0) \$$

(c) 2021. The Author(s). This is an open access article published by Thieme under the terms of the Creative Commons Attribution-NonDerivative-NonCommercial-License, permitting copying and reproduction so long as the original work is given appropriate credit. Contents may not be used for commercial purposes or adapted, remixed, transformed or built upon. (https://creativecommons.org/licenses/by-nc-nd/4.0/)

Abstract The synthesis of both enantiomers of a key intermediate in the synthesis of halofuginone was accomplished by a Candida antarctica lipase $B(C A L-B)$-catalyzed kinetic resolution of the corresponding racemate. When the resolution was carried out in the versatile solvent $c y$ clopentyl methyl ether (CPME) using p-chlorophenylbutyrate (PCPB) as the acylating reagent, the highest enantiomeric ratio $(E)$ values were measured, and highly enantioenriched ( $95 \%$ ee) compounds could be obtained in a single iteration. As an example, one of the two enantiomers was used as a starting material to prepare (+)-halofuginone in a three-step procedure.

Key words biocatalysis, lipase, kinetic resolution, halofuginone

Febrifugine (1, Figure 1) is a naturally occurring compound first isolated from the leaves of the Asian medicinal plant Dichroa febrifuga, traditionally used to reduce fever from malaria infection. ${ }^{1}$ However, translation of febrifugine into a medicine failed because of serious side effects such as nausea, vomiting, and liver damage. ${ }^{2}$ For this reason analogues were synthesized to improve the activity/toxicity profile. Amongst these, halofuginone (2, Figure 1), in which the metabolically vulnerable quinazoline protons in $\mathbf{1}$ were replaced by chlorine and bromine atoms, besides demonstrating effective antiprotozoal activity against several species of Eimeria in poultry, ${ }^{3}$ proved, in its racemic form, to possess a broad spectrum of pharmacological activities such as antifibrosis, ${ }^{4}$ antitumor, ${ }^{5}$ and growth-promoting functions. ${ }^{6}$ As reports on the biological activity of the iso- lated enantiomers of $\mathbf{2}$ are rather limited, ${ }^{7}$ in the recent decades many efforts have been devoted to the enantioselective synthesis of halofuginone, and febrifugine as well, with the $\mathrm{N}$-protected 3-hydroxypiperidine derivatives 3 (Figure $1)$, possessing $(2 R, 3 S)$ absolute configuration, being the key target intermediates. ${ }^{8-10}$
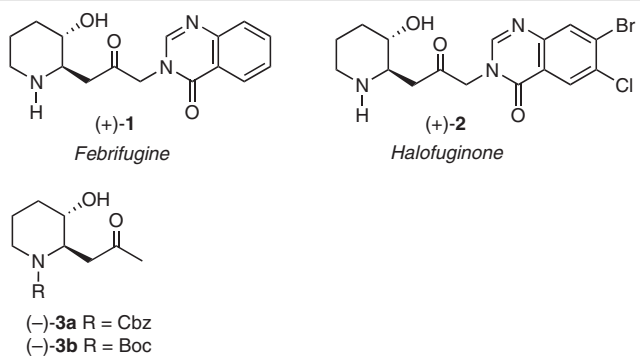

Figure 1 Structure of febrifugine (1), halofuginone (2), and 3-hydroxypiperidine derivatives 3

More recently, strategies explored for the enantioselective synthesis of $3 \mathbf{a}(\mathrm{R}=\mathrm{Cbz})$ were based on the use of starting materials from the chiral pool such as D-arabinose ${ }^{11}$ and the installation of new stereocenters by organocatalysis. ${ }^{12,13}$ Despite the tremendous efficacy of enzymes in providing enantiopure compounds, to our knowledge only Evans has reported on the enantiodivergent asymmetric synthesis of febrifugine, halofuginone, and their hemiketals based on kinetic resolution (KR) of a linear alcohol $(\mathbf{4}$, Scheme 1 , a) catalyzed by Candida antarctica lipase B. ${ }^{14}$ However, this approach required two iterations to provide one of the enantiomers (alcohol (+)-4) with high optical purity (98\% ee) but in low (27\%) overall yield. Encouraged by our recent results in the lipase-catalyzed KR of 3-hydroxypiperidine derivatives, ${ }^{15 a}$ the report by Yoshimura et al. on the efficient lipase-catalyzed KR of 3-hydroxypipecolic acid derivative $\mathbf{6}$ 
(Scheme 1, b), structurally similar to compound $3,{ }^{16}$ and in continuation of our studies on the enantioselective synthesis of (poly)hydroxypiperidine alkaloids by enzyme ${ }^{15 b, c}$ and transition-metal catalysis, ${ }^{15 \mathrm{~d}-\mathrm{j}}$ we decided to establish a practical synthetic protocol for the synthesis of both enantiomers of 3a with high optical purity by lipase-catalyzed KR of the corresponding racemate (Scheme 1, c). Moreover, looking at a possible industrial application of our approach to 3a, we decided to study this enzymatic process in both green and nonconventional media, in particular focusing on cyclopentyl methyl ether (CPME). This is a versatile solvent, suitable for applications in biotechnology and biorefineries due to its properties such as low peroxide formation rate, stability under basic and acidic conditions, relatively high boiling point, and low water solubility and water content. ${ }^{17}$ To the same end, for the synthesis of racemic 3a, we also slightly modified the shortest known route from a commercial achiral precursor in order to reduce the number of chromatographic purifications. In this way we could establish an efficient protocol of possible industrial interest, useful for rapid preparation of both enantiomers of halofuginone for comparative bioassays.

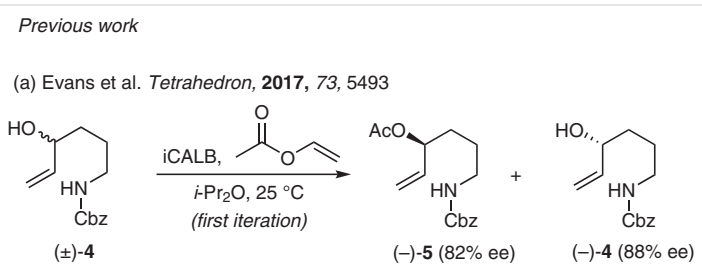

(b) Yoshimura et al. Bioorg. Med. Chem. 2008, 16, 8273
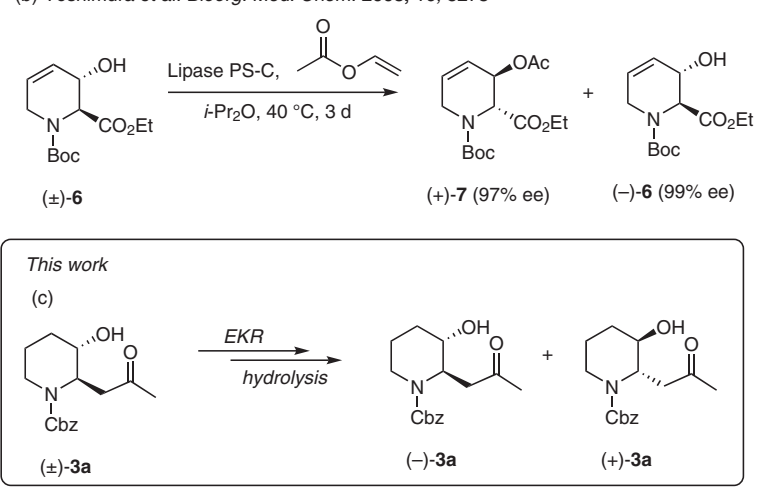

Scheme 1 Previous literature reports on EKR and the approach reported herein

Thus, commercially available, $N$-Cbz-protected $1,2,3,4-$ tetrahydropyridine 8 (Scheme 2) was treated with Oxone ${ }^{\circledR}$ ( 2 equiv) in acetone/water and in the presence of $\mathrm{K}_{2} \mathrm{CO}_{3}(2$ equiv) to obtain hemiaminal 9 ( $96 \%$ yield $)^{18}$ that, as the crude product, was subjected to Horner-WadsworthEmmons (HWE) olefination by reaction with phosphonate $\mathbf{1 0}^{19}$ to give alcohol $\mathbf{1 1}$ with $E$ geometry. ${ }^{9}$ Treatment of crude 11 with $\mathrm{BF}_{3} \cdot \mathrm{Et}_{2} \mathrm{O}$ in anhydrous acetonitrile eventually provided racemic 3a contaminated with furan derivative 12 (15\% by ${ }^{1} \mathrm{H}$ NMR analysis). ${ }^{20}$ The advantage of the HWE over the Wittig olefination of the same compound ${ }^{20 a}$ is that only one chromatography of crude 3a on silica gel is necessary to separate this product from both 12 and residual unreacted phosphonate $10 .{ }^{20 b}$ In this way, pure $( \pm)-3 a$ could be obtained in 50\% yield over the three steps and the synthesis could be rapidly carried out, usually on a $4 \mathrm{mmol}$ scale, whenever 3a was needed.

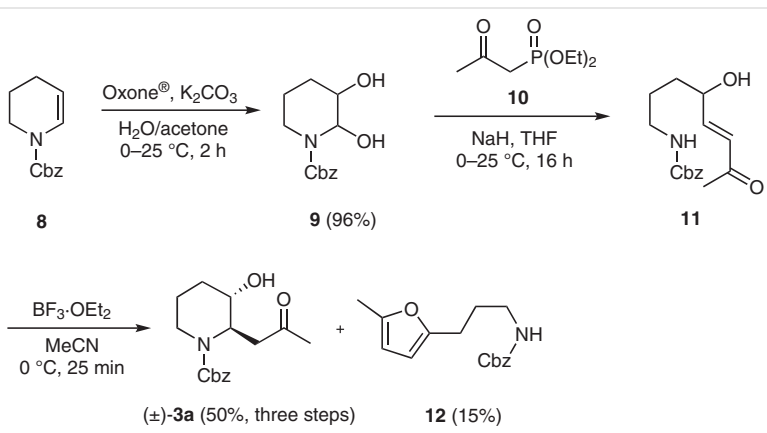

Scheme 2 Synthesis or racemic key intermediate 3

With racemic 3a in hand, we studied its enzymatic kinetic resolution (EKR) via lipase-catalyzed esterification in solvents with low water content, focusing on the use of the commercially available immobilized enzyme, iCALB (Candida antarctica lipase B immobilized on acrylic resin, Novozym $\left.^{\circledR} 435\right) .{ }^{21}$ This choice stemmed from the fact that we had successfully previously used iCALB for the kinetic resolution of hydroxylated piperidine derivatives. ${ }^{15}$ This enzyme was used as provided by the supplier without any treatment prior use but we measured its esterification activity of 1-octanol in CPME using vinyl acetate as acylating reagent at $30{ }^{\circ} \mathrm{C} .{ }^{22}$ At a substrate/enzyme ratio of $1: 10(0.19$ mmol of substrate $(\mathrm{S})$ and $1.9 \mathrm{mg}$ of immobilized enzyme (Enz)), substrate concentration $0.75 \mathrm{M}$, and 3.5 equiv of vinyl acetate, the conversion into product after 5 min was $49 \%$, corresponding to an activity value of $9.8 \times 10^{-6}$ $\mathrm{mmol}(\mathrm{S}) /[\mathrm{min} \times \operatorname{mg}(\mathrm{Enz})]$. The results of this study are reported in Tables 1 and 2 .

Starting with vinyl butyrate as the acylating agent we then screened different solvents (Table 1$)$, such as THF ( $\log P$ 0.46), to compare with the standard solvents we had used in our previous studies, ${ }^{15 a-c} 2-M e T H F(\log P 1.36)$, and CPME $(\log P 1.59) .{ }^{23}$ On the basis of very recent literature on the use of Deep Eutectic Solvents (DES) as media for biocatalyzed transformations, we also employed two $\mathrm{DES}^{24}$ obtained by mixing choline chloride with urea and glycerol, respectively. ${ }^{25}$ The reactions were monitored by GLC and stopped when the conversion was in the $40-50 \%$ range. The first experiments (Table 1, entries 1-3) were carried out with solvents dried by distillation over $\mathrm{Na}$ /benzophenone. In all cases, the iCALB lipase preferentially catalyzed esterification of the $(2 S, 3 R)$ enantiomer as determined by the 
sign of the optical rotation values (for 13a after hydrolysis), ${ }^{9}$ with comparable $E$ (enantiomeric ratio) values; ${ }^{26}$ although in CPME (and to a lesser extent in 2-MeTHF) the reaction was much faster $(7 \mathrm{~h})$. As interfacial activation is not known for this lipase, ${ }^{27}$ the higher activity in the more lipophilic CPME could be related to the increased hydrophobicity of the hydration layer, which facilitates the access of the substrate to the enzyme surface, ${ }^{28}$ and is in line with the increased activity (and selectivity) observed in this solvent in other CALB-catalyzed resolution processes. ${ }^{17}$ As the reaction was faster in CPME with a high $E$ value, we continued our study with this solvent because of its specific properties as mentioned earlier. ${ }^{17}$

Table 1 iCALB-Catalyzed Kinetic Resolution of $( \pm)$-3a in Different Solvents $^{\mathrm{a}}$

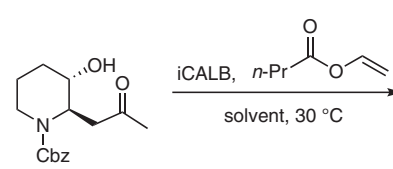

$( \pm)-3 a$

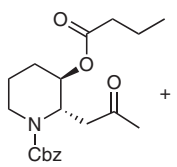

$(+)-13 a$

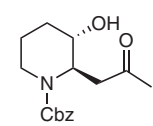

$(-)-3 a$

\begin{tabular}{|c|c|c|c|c|c|c|}
\hline Entry & Solvent & $t(h)$ & $c(\%)^{\mathrm{b}}$ & $\begin{array}{l}(+)-13 a \\
\text { ee }(\%)^{c}\end{array}$ & $\begin{array}{l}(-)-3 a \\
\text { ee }(\%)^{c}\end{array}$ & $E^{\mathrm{d}}$ \\
\hline 1 & $\mathrm{THF}^{\mathrm{e}}$ & 25 & 45 & 94 & 88 & 94 \\
\hline 2 & 2-MeTHFe & 7.5 & 39 & 97 & 64 & 127 \\
\hline 3 & CPME $^{\mathrm{e}, \mathrm{f}}$ & 7 & 46 & 94 & 84 & 86 \\
\hline 4 & $\mathrm{CPME}^{\mathrm{g}}$ & 8 & 48 & 92 & 87 & 68 \\
\hline 5 & $\mathrm{CPME}^{\mathrm{h}}$ & 8.5 & 37 & 95 & 68 & 80 \\
\hline 6 & ChCl/urea $^{i}(1: 2)$ & 118 & 16 & 93 & 24 & 35 \\
\hline 7 & $\begin{array}{l}\text { ChCl/urea }(1: 2)+ \\
\text { CPME }(10 \%)^{i, j}\end{array}$ & 120 & 21 & - & - & - \\
\hline 8 & $\begin{array}{l}\text { ChCl/glycerol } \\
(1: 2)^{\mathrm{j}}\end{array}$ & 22 & 2 & - & - & - \\
\hline
\end{tabular}

${ }^{\text {a }}$ Reaction carried out on $0.2 \mathrm{mmol}$ of substrate at $30^{\circ} \mathrm{C}$; substrate concentration: $0.76 \mathrm{M}$; enzyme $(\mathrm{mg}) /$ substrate $(\mathrm{mmol})$ ratio: $100 \mathrm{mg} \mathrm{mmol}^{-1} ; 3.5$ equiv of acylating agent.

${ }^{b}$ Reaction monitored by GLC; conversion determined by ${ }^{1} \mathrm{H}$ NMR spectroscopy.

' Determined by HPLC analysis on a HPLC Lux® $5 \mu \mathrm{m}$ Amylose-1 (250 × 4.6 $\mathrm{mm}$ ) column; for (+)-13a after hydrolysis to alcohol (+)-3a.

${ }^{d} E$ was calculated by using the formula $E=\ln \left[\left(1-e_{s}\right) /\left(1+e_{s} / e_{p}\right)\right] / \ln [(1+$ ee $\left.) /\left(1+e_{s} / e_{p}\right)\right]$ as reported in ref. 26 .

e Distilled over Na/benzophenone.

f Water content: 255 ppm.

g Commercial material; water content: 1330 ppm.

h Dried over $4 \AA$ MS and reaction was carried out in the presence of $4 \AA$ MS (130 $\mathrm{mg} \mathrm{mmol}^{-1}$ ).

Carried out at $50{ }^{\circ} \mathrm{C}$

' Carried out at a $\mathrm{C}=0.25 \mathrm{M}$

Disappointing results were obtained in the two DES we investigated (entries 6-8), in which reaction rates were unacceptably low despite several attempts at changing concentration, stirring rate, temperature, quantity of acylating agent, using crushed lipase or adding a co-solvent (data not shown). On the other hand, successful iCALB-catalyzed transesterification was observed in the two DES we investigated using a large excess of alcohol to convert vinyl laurate. ${ }^{25}$

These negative results are consistent with those obtained by Petrenz et al. who attempted a lipase-catalyzed KR of benzoin in DES with vinyl butyrate and found a much lower activity (10\% conversion after $48 \mathrm{~h}$ ) than in CPME and 2-MeTHF, most likely due to mass-transfer limitations as a result of high DES viscosity. ${ }^{29}$

We evaluated CPME as provided by the supplier, too (entry 4), observing just a slight decrease of the $E$ value (68) but not of the reaction rate. We measured the content of water in CPME before (1330 ppm) and after distillation (255 ppm) over $\mathrm{Na}$ /benzophenone by Karl Fischer titration. Our results show that the water content in commercial CPME is not sufficiently high to affect the reaction rate, for example, by competing with the substrate, at least under our conditions, but has instead a small influence on the enantioselectivity. ${ }^{30}$ The reaction rate was instead slight lower when carried out in the presence of $4 \AA$ molecular sieves (MS) and in CPME dried over 4 A MS for two days (entry 5).

The next experiments were carried out in CPME distilled over $\mathrm{Na}$ /benzophenone, changing the acylating agent, in the attempt to further improve the $E$ value (Table 2, entries 1-7). In all cases, the reaction was slower than with vinyl butyrate (Table 2 , entry 1 ) but we were very satisfied to observe that, with PCPB as the acylating agent, the $E$ value was very high (290) and the reaction was still reasonably fast ( $24 \mathrm{~h}$ to reach $46 \%$ conversion). In general, the reaction was much faster when carried out with vinyl esters (Table 2 , entries $1,6,7)$ than with esters such as TFEB and TCEA (Table 2, entries 2 and 5). Reducing the amount of enzyme to a quarter ( $25 \mathrm{mg}$ per mmol of substrate) the reaction rate was, as expected, much lower (Table 2, entries 8 and 9), without any significant effect on the enantiomeric ratio $E$. When reducing the amount of acylating agent, while we did not observe any variation in the reaction rate with vinyl butyrate (cf. Table 2, entries 9 and 11), the reaction did slow down significantly when we used PCPB (cf. Table 2, entries 3 and 10). Despite this, we opted for the latter conditions for a larger scale KR of ( \pm )-3a (and the subsequent synthesis of enantiopure halofuginone) to avoid using a relatively large excess of the acylating agent, the residual amounts of which can nevertheless be separated by chromatography and recycled.

For the synthesis of (+)-halofuginone (Scheme 3 ) we first resolved $2 \mathrm{mmol}$ of $( \pm)$-3a using iCALB under the conditions of Table 2, entry 10 . Given the high enantioselectivity of the enzyme, only one iteration was necessary to obtain in good yield highly enantioenriched compounds (-)3a (45\%, 95\% ee) and (+)-13a (44\%). Hydrolysis of (+)-13a, carried out in the presence of MeONa in anhydrous methanol, then furnished alcohol (+)-3a (95\% ee) in $89 \%$ yield. The next steps of the synthesis were carried out as reported, ${ }^{14}$ by $\alpha$-bromination of (-)-3a with $N$-bromosuccinimide 
Table 2 iCALB-Catalyzed Kinetic Resolution of ( \pm )-3a in CPME with Different Acylating Agents ${ }^{a}$

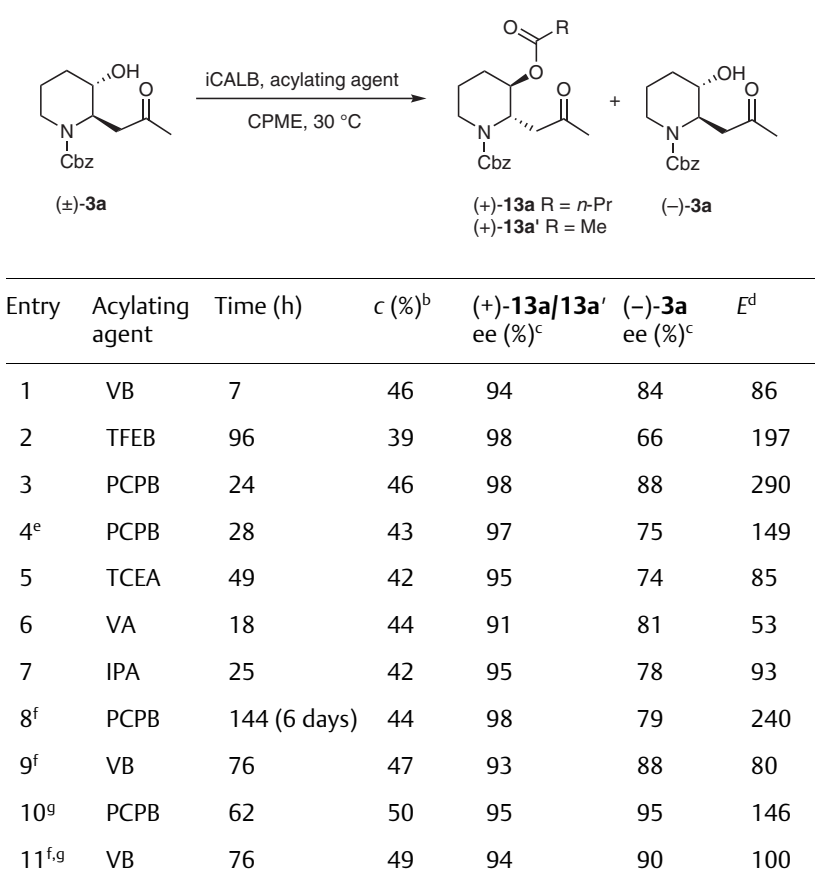

a Reaction carried out on $0.2 \mathrm{mmol}$ of substrate at $30^{\circ} \mathrm{C}$; substrate concentration: $0.76 \mathrm{M}$; enzyme $(\mathrm{mg}) /$ substrate $(\mathrm{mmol})$ ratio: $100 \mathrm{mg} \mathrm{mmol}^{-1}$; CPME distilled over $\mathrm{Na}$ /benzophenone; 3.5 equiv of acylating agent $(\mathrm{VB}=$ vinyl butyrate; $\mathrm{VA}=$ vinyl acetate; TFEB $=$ trifluoroethyl butyrate; $\mathrm{PCPB}=p$ chlorophenyl butyrate; TCEA = trichloroethyl acetate; IPA = isopropenyl acetate).

${ }^{\mathrm{b}}$ Reaction monitored by GLC; conversion and determined by ${ }^{1} \mathrm{H}$ NMR spectroscopy.

' Determined by HPLC analysis on a HPLC Lux® $5 \mu \mathrm{m}$ Amylose- $1(250 \times 4.6$ $\mathrm{mm}$ ) column; for (+)-13a/13a' after hydrolysis to alcohol (+)-3a.

${ }^{\mathrm{d}} E$ was calculated by using the formula $E=\ln \left[\left(1-\mathrm{ee}_{s}\right) /\left(1+\mathrm{ee}_{s} / \mathrm{ee}_{\mathrm{p}}\right)\right] / \ln [(1+$ $\left.\left.\mathrm{ee}_{\mathrm{S}}\right) /\left(1+\mathrm{ee}_{\mathrm{S}} / \mathrm{ee}_{\mathrm{p}}\right)\right]$ as reported in ref. 26

e CPME dried over 4 Å MS.

${ }^{\mathrm{f}}$ Enzyme $(\mathrm{mg}) /$ substrate $(\mathrm{mmol})$ ratio: $25 \mathrm{mg} \mathrm{mmol}^{-1}$.

${ }^{9}$ Carried out with 2 equiv of acylating agent.

(NBS) after generation of the corresponding silyl enol ether, followed by the reaction of $\mathbf{1 4}$ (as crude product) with commercially available cebrazolone (7-bromo-6-chloro-4(1H)quinazolinone) to give $\mathrm{N}-\mathrm{CBz}$-protected halofuginone (-)15 in $62 \%$ yield after chromatography. Finally, treatment with $\mathrm{HBr}$ in acetic acid provided (+)-halofuginone hydrobromide 2 in 57\% yield. Of course, by the same approach, (-)-halofuginone with the same optical purity (95\% ee) could be obtained from (+)-3a.

In conclusion, we have demonstrated that the enantiodivergent synthesis of a key intermediate in the preparation of halofuginone can be accomplished by its enzymatic kinetic resolution using immobilized Candida antarctica lipase $B$. When the resolution was carried out in the CPME solvent, using $p$-chlorophenylbutyrate ( $\mathrm{PCPB}$ ) as the acylating reagent, the highest enantiomeric ratio $(E)$ values were

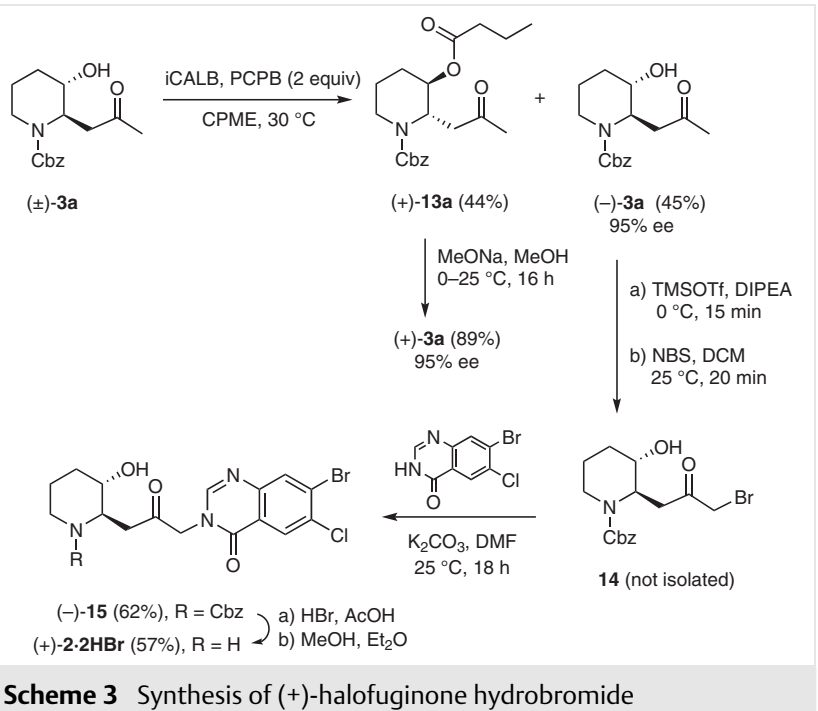

measured, providing almost enantiopure (95\% ee) compounds in a single iteration of the kinetic resolution. Since the racemic material can be quickly obtained in three steps from a commercially available piperidine derivative, with only one chromatographic purification needed, our approach is an efficient and sustainable synthesis of halofuginone for further investigating the biological properties of both enantiomers of this biologically active compound. As an illustration, one of the two enantiomers was converted into enantiopure (+)-halofuginone according to a literature procedure.

Anhydrous solvents were prepared according to the standard techniques. Commercially available reagents were used without further purification. Chromatographic separations were performed under pressure on silica gel 60 (Merck, 70-230 mesh) by using flash column techniques; $R_{f}$ values refer to TLC carried out on $0.25 \mathrm{~mm}$ silica gel plates $\left(\mathrm{F}_{254}\right)$ with the same eluent indicated for column chromatography. ${ }^{1} \mathrm{H}$ NMR (400 and $200 \mathrm{MHz}$ ) and ${ }^{13} \mathrm{C}$ NMR (100.4 MHz) spectra were recorded on Varian Inova $(400 \mathrm{MHz}$ ) and Mercury (400 and 200 $\mathrm{MHz}$ ) spectrometers in the specified deuterated solvent at $25{ }^{\circ} \mathrm{C} .{ }^{1} \mathrm{H}$ NMR $(600 \mathrm{MHz})$ and ${ }^{13} \mathrm{C}$ NMR $(150 \mathrm{MHz})$ spectra were recorded on a Jeol ECZR600 spectrometer. Solvent references were set at $\delta=7.26$ and $77.0 \mathrm{ppm}\left(\mathrm{CDCl}_{3}\right), 2.50$ and $39.5 \mathrm{ppm}\left(\mathrm{DMSO}-\mathrm{d}_{6}\right)$ in the ${ }^{1} \mathrm{H}$ NMR and ${ }^{13} \mathrm{C}$ NMR spectra, respectively. Mass spectrometric analyses were carried out by direct inlet of a $10 \mathrm{ppm}$ solution in $\mathrm{MeOH}$ into an LCQ Fleet Ion Trap LC-MS system (Thermo Fisher Scientific) with an electrospray ionization (ESI) interface in the positive ion mode. HPLC analyses were carried out with a Dionex Ultimate 3000 instrument, using a Lux $5 \mu \mathrm{m}$ Amylose- 1 column $(250 \times 4.6 \mathrm{~mm})$ and eluting at 0.5

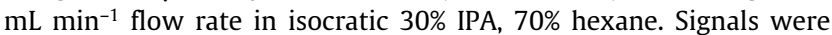
monitored at $\lambda=223 \mathrm{~nm}$ with a UV detector. Compound $\mathbf{8}$ is commercially available or can be prepared as reported. ${ }^{18}$ Compounds (+)$\mathbf{2} \cdot \mathbf{2 H B r},{ }^{14}( \pm)-3 \mathbf{a},{ }^{20}(-)-3 \mathbf{a},{ }^{9}(+)-\mathbf{3 a},{ }^{9} \mathbf{9}^{18}{ }^{10} \mathbf{1 0},{ }^{19} \mathbf{1 1},{ }^{20} \mathbf{1 4},,^{14}$ and $(-)-\mathbf{1 5}^{14}$ are known. Candida antarctica lipase B immobilized on acrylic resin (Novozym ${ }^{\circledR} 435$ ) was purchased from Strem Chemicals, Inc. 


\section{(2-0xopropyl)phosphonic Acid Diethyl Ester (10) ${ }^{19}$}

Chloroacetone ( $2 \mathrm{~mL}, 25 \mathrm{mmol}$ ) was added to a suspension of $\mathrm{KI}$ $(4.6 \mathrm{~g}, 27.5 \mathrm{mmol})$ in anhydrous $\mathrm{MeCN}(10 \mathrm{~mL})$ and anhydrous acetone $(10 \mathrm{~mL})$, and the reaction was stirred at room temperature for $1 \mathrm{~h}$. Then triethylphosphite ( $4.34 \mathrm{~mL}, 25 \mathrm{mmol}$ ) was added dropwise over $10 \mathrm{~min}$. After $16 \mathrm{~h}$, the reaction mixture was quenched with water $(20 \mathrm{~mL})$ and extracted with EtOAc $(3 \times 40 \mathrm{~mL})$. The combined organic layers were washed with water $(2 \times 60 \mathrm{~mL})$, brine $(60 \mathrm{~mL})$, dried over $\mathrm{Na}_{2} \mathrm{SO}_{4}$, filtered, and concentrated in vacuo. The yield of product $\mathbf{1 0}$ $(80 \%)$ was calculated by ${ }^{1} \mathrm{H}$ NMR analysis, using $\mathrm{MeNO}_{2}$ as internal standard. Crude $\mathbf{1 0}$ was then used without further purification.

${ }^{1} \mathrm{H}$ NMR $\left(200 \mathrm{MHz}, \mathrm{CDCl}_{3}\right): \delta=4.22-4.07(\mathrm{~m}, 4 \mathrm{H}), 3.08(\mathrm{~d}, J=22.8 \mathrm{~Hz}$, $2 \mathrm{H}), 2.32(\mathrm{~s}, 3 \mathrm{H}), 1.34(\mathrm{t}, J=7.0 \mathrm{~Hz}, 6 \mathrm{H}) \mathrm{ppm}$.

\section{3-Hydroxy-2-(2-oxopropyl)piperidine-1-carboxylic Acid Benzyl Ester (( \pm$)-3 a)$}

To a solution of $8(696 \mu \mathrm{L}, 3.6 \mathrm{mmol})$ and $\mathrm{K}_{2} \mathrm{CO}_{3}(1 \mathrm{~g}, 7.2 \mathrm{mmol})$ in acetone $(12 \mathrm{~mL})$ and water $(12 \mathrm{~mL})$ at $0{ }^{\circ} \mathrm{C}$ was added dropwise a solution of Oxone ${ }^{\circledR}(4.42 \mathrm{~g}, 7.2 \mathrm{mmol})$ in water $(30 \mathrm{~mL})$ over $5 \mathrm{~min}$, and the reaction mixture was stirred at room temperature for $2 \mathrm{~h}$. Then the mixture was poured into ice and water $(40 \mathrm{~mL})$ and, after separation of the layers, the aqueous one was extracted with EtOAc $(3 \times 40$ $\mathrm{mL})$. The combined organic layers were washed with brine $(40 \mathrm{~mL})$, dried over $\mathrm{Na}_{2} \mathrm{SO}_{4}$, filtered, and concentrated under reduced pressure to afford the crude intermediate $\mathbf{9}$ in $96 \%$ yield as a colorless oil, which was used in the next step without further purification. ${ }^{18}$

${ }^{1} \mathrm{H}$ NMR $\left(200 \mathrm{MHz}, \mathrm{CDCl}_{3}\right): \delta$ (mixture of rotamers) $=7.39-7.30(\mathrm{~m}, 5$ $\mathrm{H})$, 5.77-5.70 ( $\mathrm{m}, 1 \mathrm{H}$, major), 5.60-5.54 ( $\mathrm{m}, 1 \mathrm{H}$, minor), $5.14(\mathrm{~s}, 2 \mathrm{H}$ ), 3.96-3.77 ( $\mathrm{m}, 1 \mathrm{H}$, major), 3.68-3.51 ( $\mathrm{m}, 1 \mathrm{H}$, minor), 3.19 (td, $J=12.4$, $3.6 \mathrm{~Hz}, 1 \mathrm{H}$, minor), 3.04 (td, $J=12.8,3.2 \mathrm{~Hz}, 1 \mathrm{H}$, major), 2.34-2.21 (m, $1 \mathrm{H}$, major), 2.08-1.98 (m, $1 \mathrm{H}$, minor), 1.97-1.42 (m, $4 \mathrm{H}) \mathrm{ppm}$.

Crude 10 (1.67 g, $8.6 \mathrm{mmol}$ ) was dissolved in anhydrous THF (38 mL) and treated with $\mathrm{NaH} 60 \%(\mathrm{w} / \mathrm{w})$ in mineral oil (344 mg, $8.6 \mathrm{mmol})$ for $30 \mathrm{~min}$ at $0{ }^{\circ} \mathrm{C}$. A solution of crude hemiaminal $9(867 \mathrm{mg}, 3.45$ $\mathrm{mmol})$ in anhydrous THF $(17 \mathrm{~mL})$ was then added and the mixture allowed to warm to room temperature and stirred overnight. Then $\mathrm{Et}_{2} \mathrm{O}$ $(40 \mathrm{~mL})$ was added, and the organic layer was washed with a saturated aqueous solution of $\mathrm{NH}_{4} \mathrm{Cl}(2 \times 40 \mathrm{~mL})$, brine $(40 \mathrm{~mL})$, and dried over $\mathrm{Na}_{2} \mathrm{SO}_{4}$. After filtration and evaporation of the solvent, the oily residue containing olefin $\mathbf{1 1}$ was used as such in the next step. ${ }^{20}$

${ }^{1} \mathrm{H}$ NMR $\left(200 \mathrm{MHz}, \mathrm{CDCl}_{3}\right): \delta=7.37-7.32(\mathrm{~m}, 5 \mathrm{H}), 6.74(\mathrm{dd}, J=16.0$, $5.0 \mathrm{~Hz}, 1 \mathrm{H}), 6.27(\mathrm{dd}, J=16.0,1.4 \mathrm{~Hz}, 1 \mathrm{H}), 5.09(\mathrm{~s}, 2 \mathrm{H}), 4.94-4.85(\mathrm{~m}$, $1 \mathrm{H}), 4.29-4.23$ (m, $1 \mathrm{H}), 3.32-3.17$ ( $\mathrm{m}, 2 \mathrm{H}), 2.48-2.38$ ( $\mathrm{m}, 1 \mathrm{H}), 2.26$ (s, $3 \mathrm{H}), 1.74-1.57(\mathrm{~m}, 4 \mathrm{H}) \mathrm{ppm}$.

Crude olefin 11 (3.45 mmol) in acetonitrile $(34.5 \mathrm{~mL})$ was treated with $\mathrm{BF}_{3} \cdot \mathrm{Et}_{2} \mathrm{O}(213 \mu \mathrm{L}, 1.73 \mathrm{mmol})$ at $0{ }^{\circ} \mathrm{C}$. After $25 \mathrm{~min}$ a saturated aqueous solution of $\mathrm{NaHCO}_{3}(55 \mathrm{~mL})$ was added and the product extracted with EtOAc $(2 \times 55 \mathrm{~mL})$. The combined organic extracts were washed with brine $(30 \mathrm{~mL})$, dried over $\mathrm{Na}_{2} \mathrm{SO}_{4}$, filtered, and concentrated under reduced pressure. The crude product was purified by flash chromatography ( $n$-hexane/EtOAc, $1: 2, R_{f}=0.29$ ) to afford pure $( \pm)-3 a(582 \mathrm{mg}, 2 \mathrm{mmol}$ ) in $50 \%$ yield as a yellow oil. Spectroscopic and analytical data are identical to those reported in the literature. ${ }^{20}$

${ }^{1} \mathrm{H}$ NMR $\left(400 \mathrm{MHz}, \mathrm{CDCl}_{3}\right): \delta=7.34-7.27(\mathrm{~m}, 5 \mathrm{H}), 5.11(\mathrm{~s}, 2 \mathrm{H}), 4.73$ $(\mathrm{m}, 1 \mathrm{H}), 4.13-4.00(\mathrm{~m}, 1 \mathrm{H}), 3.84-3.75(\mathrm{~m}, 1 \mathrm{H}), 2.86(\mathrm{t}, J=12.0 \mathrm{~Hz}, 1$ H), 2.63 (d, $J=7.6 \mathrm{~Hz}, 2 \mathrm{H}) 2.14(\mathrm{br} \mathrm{s}, 3 \mathrm{H}), 1.89$ (qt, $J=13.2,4.8 \mathrm{~Hz}, 1$ $\mathrm{H}), 1.79-1.71(\mathrm{~m}, 1 \mathrm{H}), 1.70-1.60(\mathrm{~m}, 1 \mathrm{H}), 1.45-1.36(\mathrm{~m}, 1 \mathrm{H}) \mathrm{ppm}$.

\section{Lipase-Catalyzed Kinetic Resolution of ( \pm )-3a}

iCAL-B (200 mg) was added to a solution of ( \pm )-3a (582 mg, $2 \mathrm{mmol}$ ) in anhydrous CPME $(2.6 \mathrm{~mL})$ at $30{ }^{\circ} \mathrm{C}$ and, after $10 \mathrm{~min}, p$-chlorophenyl butyrate ( $795 \mathrm{mg}, 4 \mathrm{mmol}$ ) was added. The reaction mixture was stirred, and the progress of EKR process was monitored by GLC. After $72 \mathrm{~h}$, the conversion reached $50 \%$, and the reaction was stopped by filtration through a thin layer of Celite ${ }^{\circledR}$ and the filter cake was washed with EtOAc $(3 \times 5 \mathrm{~mL})$. After evaporation of the solvent, the crude product was purified by flash chromatography ( $n$-hexane/EtOAc, $1: 1$ ) to give (+)-13a (318 mg, $44 \% ; R_{f}=0.40$ ) as a colorless oil ( $95 \%$ ee), and (-)-3a (262 mg, 45\%; $\left.R_{f}=0.18\right)$ as a clear yellow oil.

\section{3-Hydroxy-2-(2-oxopropyl)piperidine-1-carboxylic Acid Benzyl Ester $((-)-3 a)^{9}$}

$[\alpha]_{D}{ }^{20}-19.9\left(c 0.68, \mathrm{CHCl}_{3}\right)$. Spectroscopic data are identical to those reported for $( \pm)-3 a$.

\section{3-Butyryloxy-2-(2-oxopropyl)piperidine-1-carboxylic Acid Benzyl Ester $((+)-13 a)$ \\ $[\alpha]_{D}^{20}+50.8\left(c 0.7, \mathrm{CHCl}_{3}\right)$.}

${ }^{1} \mathrm{H}$ NMR (400 MHz, $\mathrm{CDCl}_{3}$ ): $\delta=7.34-7.29(\mathrm{~m}, 5 \mathrm{H}$ ), 5.13 (br s, $2 \mathrm{H}$ ), 4.83 (br d, $J=38.6 \mathrm{~Hz}, 2 \mathrm{H}), 4.24-3.99(\mathrm{br} \mathrm{m}, 1 \mathrm{H}), 2.99-2.81(\mathrm{~m}, 1 \mathrm{H})$, 2.72-2.60 (m, 2 H), 2.28-2.06 (br m, 5 H), 1.84-1.73 (br m, 3 H), 1.601.44 (br m, $3 \mathrm{H}), 0.90(\mathrm{t}, J=7.2 \mathrm{~Hz}, 3 \mathrm{H}) \mathrm{ppm}$.

${ }^{13} \mathrm{C}$ NMR $\left(100.4 \mathrm{MHz}, \mathrm{CDCl}_{3}\right): \delta$ (mixture of rotamers) $=205.9$ and 205.0, 172.8, 155.7, 136.6, 128.4 (2 C), 127.9, 127.8 (2 C), 68.9, 67.2, $51.1,43.4,38.9,36.2,29.7,23.7,19.6,18.3,13.6 \mathrm{ppm}$.

MS (ESI): $m / z(\%)=745[2 \mathrm{M}+\mathrm{Na}]^{+}(100), 384[\mathrm{M}+\mathrm{Na}]^{+}(55)$.

Anal. Calcd for $\mathrm{C}_{20} \mathrm{H}_{27} \mathrm{NO}_{5}$ : C, 66.46; $\mathrm{H}, 7.53 ; \mathrm{N}, 3.88$. Found: C, 66.27; $\mathrm{H}, 7.31 ; \mathrm{N}, 3.76$

\section{3-Hydroxy-2-(2-oxopropyl)piperidine-1-carboxylic Acid Benzyl Ester $((+)-3 a)^{9}$}

To a solution of $(+)-\mathbf{1 3 a}(318 \mathrm{mg}, 0.88 \mathrm{mmol}$ ) in anhydrous $\mathrm{MeOH}(6$ $\mathrm{mL}$ ) cooled to $0{ }^{\circ} \mathrm{C}$ was added $\mathrm{MeONa}(95 \mathrm{mg}, 1.76 \mathrm{mmol})$, and the reaction was stirred at room temperature overnight. A saturated aqueous solution of $\mathrm{NH}_{4} \mathrm{Cl}(880 \mu \mathrm{L})$ was then added and the reaction mixture concentrated under reduced pressure. Water $(88 \mathrm{~mL})$ and EtOAc ( $88 \mathrm{~mL}$ ) were added to the residue, and, after separation of the phases, the aqueous phase was further extracted with EtOAc $(3 \times 50$ $\mathrm{mL}$ ) and the combined organic extracts were dried over $\mathrm{Na}_{2} \mathrm{SO}_{4}$. After filtration and evaporation of the solvent, crude (+)-3a was purified by flash chromatography ( $n$-hexane/EtOAc, $1: 1 ; R_{f}=0.18$ ), affording pure $(+)-3 a(227 \mathrm{mg}, 89 \%)$ as a clear yellow oil (95\% ee). $[\alpha]_{D}{ }^{20}+23.2(c 0.7$, $\mathrm{CHCl}_{3}$ ). Spectroscopic data are identical to those reported for $( \pm)-3 \mathbf{a}$.

2-[3-(7-Bromo-6-chloro-4-oxo-4H-quinazolin-3-yl)-2-oxopropyl]3-hydroxypiperidine-1-carboxylic Acid Benzyl Ester [(-)- $\mathrm{N}-\mathrm{Cbz}-$ Protected Halofuginone, (-)-15 $]^{14}$

DIPEA (502 $\mu \mathrm{L}, 2.88 \mathrm{mmol}$ ) and TMSOTf (521 $\mu \mathrm{L}, 2.88 \mathrm{mmol})$ were added to a solution of (-)-3a (262 $\mathrm{mg}, 0.90 \mathrm{mmol})$ in anhydrous DCM $(16 \mathrm{~mL})$, cooled to $0{ }^{\circ} \mathrm{C}$ (ice bath). After $20 \mathrm{~min}$, NBS (224 mg, 1.26 $\mathrm{mmol}$ ) was added, the ice bath removed and, after $20 \mathrm{~min}$, the reaction was stopped by dilution with DCM $(16 \mathrm{~mL})$. The organic solvent was washed with water $(2 \times 16 \mathrm{~mL})$, brine $(16 \mathrm{~mL})$, and dried over $\mathrm{Na}_{2} \mathrm{SO}_{4}$. After filtration and evaporation of the solvent, crude $\alpha$-brominated intermediate $\mathbf{1 4}$ was obtained and used as such in the next step. 
${ }^{1} \mathrm{H}$ NMR $\left(400 \mathrm{MHz}, \mathrm{CDCl}_{3}\right): \delta$ (mixture of rotamers) $=7.38-7.28(\mathrm{~m}, 5$ H), $5.11(\mathrm{~s}, 2 \mathrm{H}), 4.72(\mathrm{t}, J=6.8 \mathrm{~Hz}, 1 \mathrm{H}), 4.05$ (br s, $1 \mathrm{H}), 3.83$ (br s, $2 \mathrm{H}$ ), $3.01-2.87(\mathrm{~m}, 2 \mathrm{H}), 2.84(\mathrm{~d}, J=8.0 \mathrm{~Hz}, 2 \mathrm{H}$, major $), 2.80(\mathrm{~d}, J=8.0 \mathrm{~Hz}, 2$ $\mathrm{H}$, minor), $2.85-2.79(\mathrm{~m}, 1 \mathrm{H}), 1.89$ (qt, $J=12.8,4.4 \mathrm{~Hz}, 1 \mathrm{H}), 1.82-1.73$ (m, $1 \mathrm{H}), 1.72-1.63(\mathrm{~m}, 1 \mathrm{H}), 1.48-1.39(\mathrm{~m}, 1 \mathrm{H}) \mathrm{ppm}$.

Crude 14 was dissolved in anhydrous DMF $(10 \mathrm{~mL})$ and reacted with 7-bromo-6-chloro-4(1H)-quinazolinone (cebrazolone, $234 \mathrm{mg}, 0.90$ $\mathrm{mmol}$ ) in the presence of $\mathrm{K}_{2} \mathrm{CO}_{3}(124 \mathrm{mg}, 0.90 \mathrm{mmol})$ at room temperature. After $18 \mathrm{~h}$, the reaction mixture was diluted with EtOAc (20 $\mathrm{mL})$, washed with water $(2 \times 20 \mathrm{~mL})$, and, after separation of the phases, the aqueous phase was further extracted with EtOAc $(3 \times 20$ $\mathrm{mL}$ ). The combined organic extracts were washed with brine $(40 \mathrm{~mL})$ and dried over $\mathrm{Na}_{2} \mathrm{SO}_{4}$. After filtration and evaporation of the solvent, the crude product was purified by flash chromatography (EtOAc; $R_{f}=$ 0.17 ) to afford (-)- $N$-Cbz-protected halofuginone (-)-15 (307 mg, $62 \%)$ as a white solid. Spectroscopic and analytical data are in accordance with those reported. ${ }^{14}$

$[\alpha]_{D}^{21}-21.4\left(c 0.59, \mathrm{CHCl}_{3}\right)$.

${ }^{1} \mathrm{H}$ NMR (400 MHz, $\left.\mathrm{CDCl}_{3}\right): \delta=8.28(\mathrm{~s}, 1 \mathrm{H}), 8.00$ (s, $\left.1 \mathrm{H}\right), 7.95$ (br s, 1 $\mathrm{H}), 7.35-7.28(\mathrm{~m}, 5 \mathrm{H}), 5.11(\mathrm{~s}, 2 \mathrm{H}), 5.01-4.78(\mathrm{~m}, 1 \mathrm{H}), 4.71(\mathrm{t}, J=6.4$ Hz, $1 \mathrm{H}), 4.07-3.95(\mathrm{~m}, 1 \mathrm{H}), 3.88(\mathrm{~s}, 1 \mathrm{H}), 3.08-2.96$ (m, $1 \mathrm{H}), 2.85-$ 2.77 ( $\mathrm{m}, 2 \mathrm{H}), 2.60$ (br s, $1 \mathrm{H}), 1.90(\mathrm{qt}, J=12.8,4.4 \mathrm{~Hz}, 1 \mathrm{H}), 1.83-1.72$ (m, $2 \mathrm{H}), 1.51-1.43(\mathrm{~m}, 1 \mathrm{H}), 0.90-0.80(\mathrm{~m}, 1 \mathrm{H}) \mathrm{ppm}$.

2-[3-(7-Bromo-6-chloro-4-oxo-4H-quinazolin-3-yl)-2-oxopropyl]3-hydroxypiperidinium Bromide ((+)-2-2HBr $)^{14}$

(-)-N-Cbz-protected halofuginone (-)-15 (307 mg, $0.56 \mathrm{mmol}$ ) in 33\% $\mathrm{HBr}$ in $\mathrm{AcOH}(8.4 \mathrm{~mL})$ was stirred at room temperature for $3 \mathrm{~h}$. Then the reaction mixture was diluted with $\mathrm{MeOH}(8.4 \mathrm{~mL})$, triturated with $\mathrm{Et}_{2} \mathrm{O}(3 \times 8.4 \mathrm{~mL})$ and dried under reduced pressure to afford $(+)-$ 2.2HBr (184 mg, 57\%) as a white solid with analytical and spectroscopic data in accordance with those reported in the literature. ${ }^{14}$

${ }^{1} \mathrm{H}$ NMR $\left(600 \mathrm{MHz}\right.$, DMSO- $\left.d_{6}\right): \delta=8.79-8.67(\mathrm{~m}, 2 \mathrm{H}), 8.30(\mathrm{~s}, 1 \mathrm{H})$, $8.22(\mathrm{~s}, 1 \mathrm{H}), 8.17$ (s, $1 \mathrm{H}), 5.14-5.08(\mathrm{~m}, 2 \mathrm{H}), 3.53$ (td, $J=9.6,4.2 \mathrm{~Hz}, 1$ H), 3.35-3.29 (m, $1 \mathrm{H}), 3.23$ (dd, $J=17.4,5.4 \mathrm{~Hz}, 1 \mathrm{H}), 3.18-3.13$ (m, 1 H), $2.93(\mathrm{dd}, J=17.4,6.0 \mathrm{~Hz}, 1 \mathrm{H}), 2.92-2.85(\mathrm{~m}, 1 \mathrm{H}), 1.94-1.89(\mathrm{~m}, 1$ H), 1.83-1.77 (m, $1 \mathrm{H}), 1.68-1.59(\mathrm{~m}, 1 \mathrm{H}), 1.48-1.42(\mathrm{~m}, 1 \mathrm{H}) \mathrm{ppm}$.

${ }^{13} \mathrm{C}$ NMR $\left(150 \mathrm{MHz}, \mathrm{DMSO}-d_{6}\right): \delta=200.7,158.7,149.6,147.3,132.5$, $131.9,128.5,126.9,121.8,66.8,56.2,54.5,43.0,30.6,20.2$ ppm.

\section{Conflict of Interest}

The authors declare no conflict of interest.

\section{Funding Information}

This research was supported by Huvepharma ${ }^{\circledR}$ Italia and by the University of Florence.

\section{Acknowledgment}

The authors acknowledge Prof. Marco Ginepro for KF measurements.

\section{Supporting Information}

Supporting information for this article is available online at https://doi.org/10.1055/a-1523-6428.

\section{References and Notes}

(1) (a) Koepfli, J. B.; Mead, J. F.; Brockman, J. A. Jr. J. Am. Chem. Soc. 1947, 69, 1837. (b) Koepfli, J. B.; Mead, J. F.; Brockman, J. A. Jr. J. Am. Chem. Soc. 1949, 71, 1048.

(2) (a) Hirai, S.; Kikuchi, H.; Kim, H.-S.; Begum, K.; Wataya, Y.; Tasaka, H.; Miyazawa, Y.; Yamamoto, K.; Oshima, Y. J. Med. Chem. 2003, 46, 4351. (b) Zhu, S.; Meng, L.; Zhang, Q.; Wei, L. Bioorg. Med. Chem. Lett. 2006, 16, 1854. (c) Kikuchi, H.; Yamamoto, K.; Horoiwa, S.; Hirai, S.; Kasahara, R.; Hariguchi, N.; Matsumoto, M.; Oshima, Y. J. Med. Chem. 2006, 49, 4698. (d) Zhu, S.; Zhang, Q.; Gudise, C.; Wei, L.; Smith, E.; Zeng, Y. Bioorg. Med. Chem. 2009, 17, 4496.

(3) (a) Anderson, A.; Goodall, E.; Bliss, G. W.; Woodhouse, R. N. J. Chromatogr. 1981, 212, 347. (b) Zhang, D. F.; Sun, B. B.; Yue, Y. Y.; Yu, H. J.; Zhang, H. L.; Zhou, Q. J.; Du, A. F. Parasitol. Res. 2012, 111, 695. (c) Ramadan, A.; Abo el-Sooud, K.; El-Bahy, M. M. Res. Vet. Sci. 1997, 62, 175.

(4) (a) Granot, I.; Halevy, O.; Hurwitz, S.; Pines, M. Biochim. Biophys. 1993, 1156, 107. (b) Pines, M. World J. Gastroenterol. 2014, 20, 14778. (c) Yavas, G.; Calik, M.; Calik, G.; Yavas, C.; Ata, O.; Esme, H. Med. Hypotheses 2013, 80, 357.

(5) (a) Lamora, A.; Mullard, M.; Amiaud, J.; Brion, R.; Heymann, D.; Redini, F.; Verrecchia, F. Oncotarget 2015, 6, 14413. (b) Cook, J. A.; Choudhuri, R.; Degraff, W.; Gamson, J.; Mitchell, J. B. Cancer Lett. 2010, 289, 119. (c) Yee, K. O.; Connolly, C. M.; Pines, M.; Lawler, J. Cancer Biol. Ther. 2006, 5, 218.

(6) Casey, N. H.; Crosley, R. I.; Smith, G. A. J. S. Afr. Vet. Assoc. 1992, $63,16$.

(7) Linder, M. R.; Heckeroth, A. R.; Najdrowski, M.; Daugschies, A.; Schollmeyer, D.; Miculka, C. Bioorg. Med. Chem. Lett. 2007, 17, 4140.

(8) The absolute configuration of febrifugine was determined in 1999 by its total synthesis. See: Kobayashi, S.; Ueno, M.; Suzuki, R.; Ishitani, H.; Kim, H.-S.; Wataya, Y. J. Org. Chem. 1999, 64, 6833.

(9) McLaughlin, N. P.; Evans, P. J. Org. Chem. 2010, ; and references therein for a list of papers published prior to 201075,518 .

(10) For a review, see: (a) Smullen, S.; McLaughlin, N. P.; Evans, P. Bioorg. Med. Chem. 2018, 26, 2199. See also: (b) Zhang, J.; Yao, Q.; Liu, Z. Molecules 2017, 22, 1086; and references therein.

(11) Perali, R. S.; Bandi, A. Tetrahedron Lett. 2020, 61, 152151.

(12) Smullen, S.; Evans, P. Tetrahedron Lett. 2018, 59, 1627.

(13) Pansare, S. V.; Paul, E. K. Synthesis 2013, 45, 1863.

(14) Smullen, S.; Evans, P. Tetrahedron 2017, 73, 5493.

(15) (a) Begliomini, S.; Sernissi, L.; Scarpi, D.; Occhiato, E. G. Eur. J. Org. Chem. 2014, 5448. (b) Occhiato, E. G.; Casini, A.; Guarna, A.; Scarpi, D. Eur. J. Org. Chem. 2011, 6544. (c) Bartali, L.; Casini, A.; Guarna, A.; Occhiato, E. G.; Scarpi, D. Eur. J. Org. Chem. 2010, 5831. (d) Occhiato, E. G.; Scarpi, D.; Guarna, A.; Tabasso, S.; Deagostino, A.; Prandi, C. Synthesis 2009, 3611. (e) Bartali, L.; Scarpi, D.; Guarna, A.; Prandi, C.; Occhiato, E. G. Synlett 2009, 913. (f) Scarpi, D.; Avataneo, O.; Prandi, C.; Venturello, P.; Occhiato, E. G. Synthesis 2012, 44, 3688. (g) Scarpi, D.; Bartali, L.; Casini, A.; Occhiato, E. G. Eur. J. Org. Chem. 2012, 2597. (h) Scarpi, D.; Bartali, L.; Casini, A.; Occhiato, E. G. Eur. J. Org. Chem. 2013, 1306. (i) Sernissi, L.; Petrović, M.; Scarpi, D.; Guarna, A.; Trabocchi, A.; Bianchini, F.; Occhiato, E. G. Chem. Eur. J. 2014, 20, 11187. (j) Scarpi, D.; Begliomini, S.; Prandi, C.; Oppedisano, A.; Deagostino, A.; Gómez-Bengoa, E.; Fiser, B.; Occhiato, E. G. Eur. J. Org. Chem. 2015, 3251. 
(16) Yoshimura, Y.; Ohara, C.; Imahori, T.; Saito, Y.; Kato, A.; Miyauchi, S.; Adachi, I.; Takahata, H. Bioorg. Med. Chem. 2008, $16,8273$.

(17) de Gonzalo, G.; Alcántara, A. R.; de María, P. D. ChemSusChem 2019, 12, 2083.

(18) Takeuchi, Y.; Azuma, K.; Oshige, M.; Abe, H.; Nishioka, H.; Sasaki, K.; Harayama, T. Tetrahedron 2003, 59, 1639.

(19) Schnaars, C.; Hansen, T. Org. Lett. 2012, 14, 2794.

(20) (a) Sukemoto, S.; Oshige, M.; Sato, M.; Mimura, K.-i.; Nishioka, H.; Abe, H.; Harayama, T.; Takeuchi, Y. Synthesis 2008, 3081. (b) When we attempted a Wittig olefination, we found that two consecutive chromatographic separations were necessary to obtain pure 3a; one on silica gel to remove $\mathbf{1 2}$ and the excess of ylide, and a second one on alumina to remove triphenylphosphine oxide.

(21) (a) Akai, S.; Tanimoto, K.; Kita, Y. Angew. Chem. Int. Ed. 2004, 43, 1407. (b) Rotticci, D.; Norin, T.; Hult, K. Org. Lett. 2000, 2, 1373. (c) Orrenius, C.; Norin, T.; Hult, K.; Carrea, G. Tetrahedron: Asymmetry 1995, 6, 3023.

(22) Secundo, F.; Carrea, G.; Soregaroli, C.; Varinelli, D.; Morrone, R. Biotechnol. Bioeng. 2001, 73, 157.

(23) LogP is well known to influence enzymatic activity. See, for example: (a) Zieniuk, B.; Fabiszewska, A.; Białecka-Florjańczyk, E. Bioprocess Biosyst Eng. 2020, 43, 605. (b) Inagaki, T.; Tasada, K.; Kayahara, H. Biosci., Biotechnol., Biochem. 1994, 58, 1439.
(24) (a) Pätzold, M.; Siebenhaller, S.; Kara, S.; Liese, A.; Syldatk, C.; Holtmann, D. Trends Biotechnol. 2019, 37, 943. (b) Aranda, C.; de Gonzalo, G. Molecules 2020, 25, 3016. (c) Guajardo, N.; Domínguez, de. María P. ChemCatChem 2019, 11, 3128. (d) Panić, M.; Radović, M.; Maros, I.; Tušek, A. J.; Bubalo, M. C.; Redovniković, I. R. Process Biochem. 2021, 102, 1.

(25) Durand, E.; Lecomte, J.; Baréa, B.; Piombo, G.; Dubreucq, E.; Villeneuve, P. Process Biochem. 2012, 47, 2081.

(26) The enantioselectivity in an enzymatic kinetic resolution process is expressed by the enantiomeric ratio $E$, which is the ratio between the specificity constants $(\mathrm{kcat} / \mathrm{KM})$ of the enzyme for the competing $R$ and $S$ enantiomers: $E=$ $(\mathrm{kcat} / \mathrm{KM})_{\mathrm{R}} /(\mathrm{kcat} / \mathrm{KM})_{\mathrm{S}}$. $E$ was calculated by using the formula $E=\ln \left[\left(1-\mathrm{ee}_{\mathrm{s}}\right) /\left(1+\mathrm{ee}_{\mathrm{s}} / \mathrm{ee}_{\mathrm{p}}\right)\right] / \ln \left[\left(1+\mathrm{ee}_{\mathrm{s}}\right) /\left(1+\mathrm{ee}_{\mathrm{s}} / \mathrm{ee}_{\mathrm{p}}\right)\right]$. See: Rakels, J. L. L.; Straathof, A. J. J.; Heijnen, J. Enzyme Microb. Technol. 1993, 15, 1051.

(27) Stauch, B.; Fisher, S. J.; Cianci, M. J. Lipid Res. 2015, 56, 2348.

(28) Zieniuk, B.; Fabiszewska, A.; Białecka-Florjańczyk, E. Bioprocess Biosyst. Eng. 2020, 43, 605.

(29) Petrenz, A.; de María, P. D.; Ramanathan, A.; Hanefeld, U.; Ansorge-Schumacher, M. B.; Kara, S. J. Mol. Catal. B: Enzym. 2015, 114, 42.

(30) Léonard-Nevers, V.; Marton, Z.; Lamare, S.; Hult, K.; Graber, M. J. Mol. Catal. B: Enzym. 2009, 59, 90. 